\title{
ARAHAN PENGEMBANGAN AGROINDUSTRI KARET DALAM PENINGKATAN EKONOMI WILAYAH DI KABUPATEN ROKAN HULU, PROVINSI RIAU
}

\author{
Direction of Agroindustry Development Rubber to Promote Regional \\ Economic Growth in Rukan Hulu Regency, Riau Province
}

Yeni Selfia ${ }^{1}$, Ernan Rustiadi², Andrea Emma Pravitasari ${ }^{3}$

Diterima: 22 Juli 2017

Disetujui: 25 April 2018

\begin{abstract}
Abstrak: Tingginya produksi tanaman karet di Kabupaten Rokan Hulu belum meningkatkan kesejahteraan petani karet karena belum adanya industri pengolahan karet sehingga karet dijual dalam bentuk produk primer. Tujuan penelitian ini adalah menganalisis margin pemasaran getah karet dalam tiap tingkat pemasaran, menganalisis peran agroindustri karet dalam ekonomi wilayah, menyusun arahan pengembangan agroindustri karet dalam peningkatan ekonomi wilayah di Kabupaten Rokan Hulu. Metode yang digunakan adalah analisis margin pemasaran, analisis input output, dan AHP (Analisis Hirarki Proses). Hasil penelitian menunjukkan terdapat tiga jalur pemasaran getah karet di Kabupaten Rokan Hulu, jalur pemasaran II dan III dianggap jalur yang paling menguntungkan petani karet. Sektor karet remah dan karet asap di Kabupaten Rokan Hulu memiliki peran strategis untuk menumbuhkan sektor-sektor lainnya, dan juga banyak memanfaatkan output sektor-sektor lain sebagai input produksinya. Pengembangan agroindustri karet diharapkan sampai pada tahap pengembangan industri karet antara yang menghasilkan produk seperti karet remah dan lembaran. Upaya awal meningkatkan sumberdaya manusia yang berkualitas agar kelembagaan agroindustri karet dapat berfungsi maksimal.
\end{abstract}

Kata kunci: agroindustri karet, input-output, AHP, ekonomi wilayah.

\begin{abstract}
The high production of rubber plantation in Rokan Hulu Regency has not improved the welfare of rubber farmers because the lack of rubber processing industry, therefore the rubber is sold in the form of primary products. The objectives of this research are, analyze the rubber latex marketing margin in each marketing level, analyze the role of rubber agroindustry in regional economy, and formulate the orientation of rubber agro-industry development in improving the regional economy in Rokan Hulu Regency. The method used in this research were marketing margin analysis, input output analysis, and AHP (Analysis Hierarchy Process). The result of the research shows that there are 3 rubber marketing channels in Rokan Hulu Regency. Crumb rubber and smoke rubber sector in Rokan Hulu Regency have a strategic role to grow other sector, as well as utilizes the output of other sectors as an input. Rubber agroindustry development orientation are expected to be at the stage of developing the rubber industry between producing products such as crumb rubber and sheets. Initial efforts that can be done by increasing human resources to be more qualified so that rubber agro-industry institutions can have maximum function.
\end{abstract}

Keywords: rubber agro-industry, input-output, AHP, regional economy

\footnotetext{
${ }^{1}$ Program Studi Ilmu Perencanaan Wilayah, Institut Pertanian Bogor

${ }^{2}$ Fakultas Pertanian, Institut Pertanian Bogor

Korespondensi: yeniselfiapw12015@gmail.com
} 


\section{PENDAHULUAN}

Keberadaan tanaman karet di Indonesia menempati posisi penting dalam menopang perekonomian bangsa, baik sebagai penghasil devisa negara dari sektor non migas juga sebagai sumber mata pencaharian petani. Statistik Perkebunan Indonesia mencatat bahwa jumlah produksi karet di Indonesia pada tahun 2014 sebesar 3.153.19 ton meningkat menjadi 3.231.825 ton pada tahun 2015, dan menempati urutan kedua setelah kelapa sawit. Perkebunan karet yang ada di Indonesia pada umumnya merupakan perkebunan rakyat sebesar 85\% (BPS Indonesia 2014). Status industri karet Indonesia akan berubah dari pemasok bahan mentah menjadi pemasok barang jadi atau setengah jadi yang bernilai tambah lebih tinggi dengan melakukan pengelolahan lebih lanjut dari hasil karet, sehingga produksi karet sangat tergantung pada teknologi dan manajemen yang diterapkan dalam sistem dan proses produksinya. Produk industri karet perlu disesuaikan dengan kebutuhan pasar yang senantiasa berubah. Hal ini akan memicu munculnya basis pengembangan investasi, agribisnis dan agroindustri yang mampu memasuki pasar global.

Kabupaten Kampar dan Kabupaten Rokan Hulu merupakan daerah penghasil karet di Provinsi Riau. Hal ini terlihat dari luasnya lahan perkebunan karet serta tingginya jumlah produksi getah karet yang dihasilkan. Luas tanaman karet di Kabupaten Kampar seluas 102.353 ha dengan rincian 14.551 ha Tanaman Belum Menghasilkan (TBM), 67.045 ha Tanaman Menghasilkan (TM), dan 20.757 ha Tanaman Tidak Menghasilkan (TTM), dari luasan tersebut 8.156 ha adalah milik perusahaan besar negara, 1.273 ha milik perkebunan besar swasta, dan 92.924 ha adalah perkebunan rakyat. Produksi tanaman karet di Kabupaten Kampar pada tahun 2015 sebesar 77.556 ton dengan jumlah petani yang mengusahakan komoditi ini sebanyak 51.674 KK (BPS Kabupaten Kampar 2015).

Produksi dan luas tanaman karet di Kabupaten Kampar telah berkembang ke tahap industri pengolahan karet, terdapat 3 perusahaan yang menggunakan input produksi dari tanaman karet yakni PT. P\&P Bangkinang (Simalinyang), PT. Hervenia Kampar Lestari yang dikelola oleh Swasta dengan produk industri yang dihasilkan berupa Standar Indonesia Rubber (Sir 20) atau karet bongkah, adapun PT. Perkebunan Nusantara V Sei Lindai yang dikelola oleh Negara memproduksi crumb rubber. Keberadaan industri pengolahan karet tersebut telah berkontribusi terhadap peningkatan ekonomi wilayah di Kabupaten Kampar yang dilihat dari peningkatan subkategori industri karet, barang dari karet dan plastik dalam PDRB sebesar 11,11\% di tahun 2015.

Kabupaten Rokan Hulu juga merupakan salah satu daerah penghasil karet di Provinsi Riau. Statistik Perkebunan Indonesia Komoditas Karet tahun 2015 mencatat bahwa secara keseluruhan tanaman karet yang terdapat di Kabupaten Rokan Hulu seluas 45.499 ha. Perkebunan karet yang terdapat di Kabupaten Rokan Hulu merupakan perkebunan rakyat seluas 45.245 ha dengan rincian 43.437 ha Tanaman Menghasilkan (TM), 413 ha Tanaman Belum Menghasilkan (TBM), dan 1.395 ha tanaman tidak menghasilkan, jumlah produksinya mencapai 44.840 ton dan diusahakan oleh $18.882 \mathrm{KK}$ petani, selain itu terdapat juga perkebunan besar swasta yang menguasai lahan karet sebesar 254 ha dengan produksi 380 ton dan serapan tenaga kerja sebanyak 127 TK (BPS Kabupaten Rokan Hulu 2015).

Tingginya produksi tanaman karet di Kabupaten Rokan Hulu ternyata belum memberikan kontribusi yang nyata dalam peningkatan kesejahteraan petani karet. Hal ini dikarenakan belum adanya industri pengolahan karet sehingga karet dijual dalam bentuk produk primer (getah segar), padahal karet merupakan tanaman yang mempunyai multi manfaat karena hampir semua bagian dari karet dapat diolah menjadi produk yang mempunyai nilai ekonomi tinggi. Saat ini pemerintah Kabupaten Rokan Hulu menargetkan untuk menjadikan Kabupaten Rokan Hulu sebagai sentra produksi karet terbesar pada tahun 2020, karena itu pemerintah Kabupaten Rokan Hulu telah mengupayakan membuka 
peluang investasi untuk industri pengolahan hasil tanaman karet. Potensi tanaman karet yang ada saat ini akan diupayakan menjadi peluang Kabupaten Rokan Hulu untuk meningkatkan produksi dan industri hilir melalui pengembangan agroindustri karet. Menurut Saragih (2010) sektor agroindustri adalah industri yang memiliki keterkaitan ekonomi baik langsung maupun tidak langsung yang kuat dengan komoditas pertanian.

Penelitian ini bertujuan untuk merumuskan arahan pengembangan agroindustri karet dalam peningkatan ekonomi wilayah di Kabupaten Rokan Hulu. Untuk mencapai tujuan tersebut maka dilakukan langkah untuk (1) menganalisis margin pemasaran getah karet dalam tiap tingkat pemasaran di Kabupaten Rokan Hulu; (2) menganalisis peran agroindustri karet dalam ekonomi wilayah di Kabupaten Kampar dan Kabupaten Rokan Hulu; (3) merumuskan arahan pengembangan agroindustri karet dalam peningkatan ekonomi wilayah di Kabupaten Rokan Hulu.

\section{METODE PENELITIAN}

\section{Kerangka Pemikiran}

Kabupaten Kampar dan Kabupaten Rokan Hulu masing-masing memiliki luas lahan dan produktifitas tanaman karet yang tinggi di Provinsi Riau. Namun, di Kabupaten Kampar telah berkembang industri pengolahan karet yang dapat memberikan peningkatkan nilai tambah produk dari tanaman karet sehingga memberikan efek terhadap peningkatan ekonomi wilayah serta menyebabkan pendapatan petani karet di Kabupaten Kampar menjadi bertambah. Kondisi yang berbeda terjadi di Kabupaten Rokan Hulu yaitu karet masih dijual dalam bentuk produk primer (getah karet), hal ini dikarenakan belum adanya industri pengolahan karet. Akibatnya, Kabupaten Rokan tidak mendapatkan nilai tambah (surplus) yang seharusnya didapatkan. Oleh karena itu, sebagai upaya untuk meningkatkan nilai tambah produk dari tanaman karet perlu dilakukan suatu kajian efek agroindustri di Kabupaten Kampar. Menurut Saragih (2010) sektor agroindustri adalah industri yang memiliki keterkaitan ekonomi baik langsung maupun tidak langsung yang kuat dengan komoditas pertanian. Keterkaitan langsung mencakup hubungan komoditas pertanian sebagai bahan baku bagi kegiatan agroindustri maupun kegiatan pemasaran dan perdagangan yang memasarkan produk akhir agroindustri. Hal tersebut dapat menjadi masukan bagi pengembangan agroindustri di Kabupaten Rokan Hulu. Sistematika pemikiran dari penelitian ini seperti terlihat pada Gambar 1.

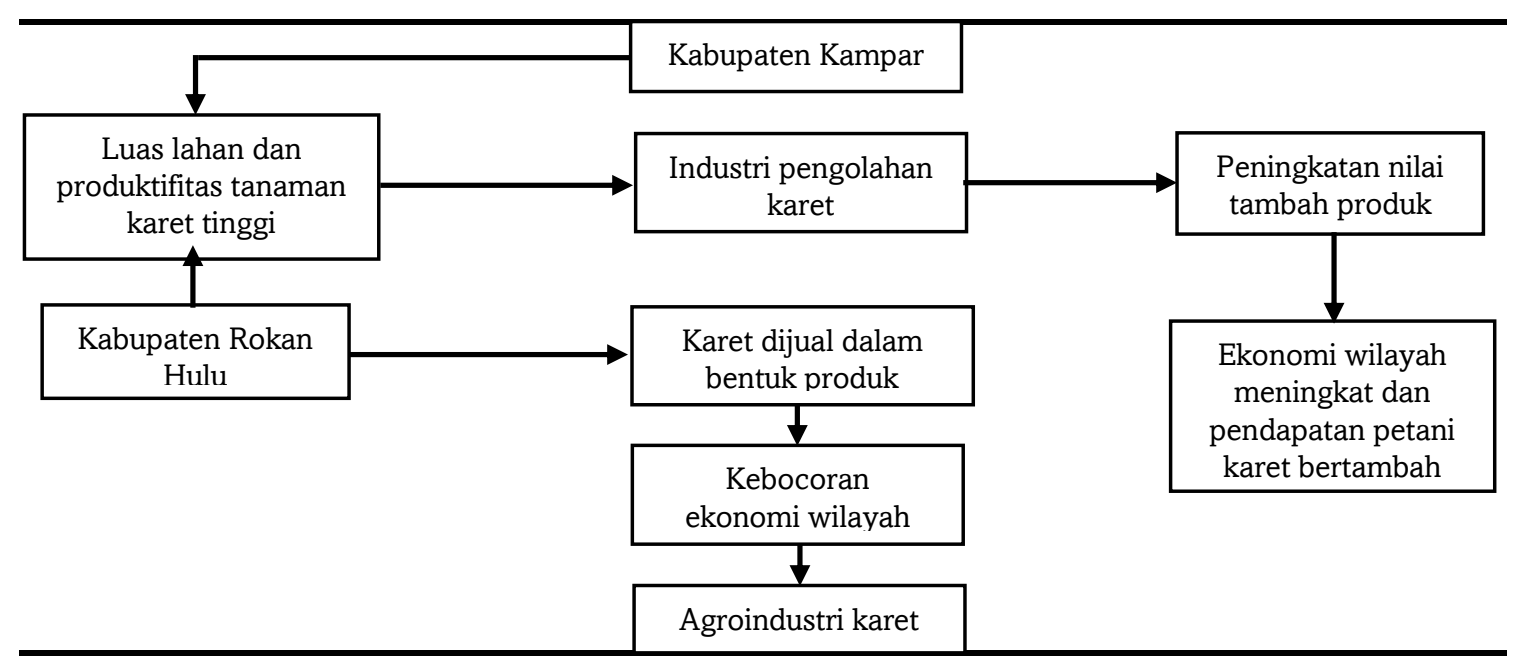

Gambar 1. Kerangka Pemikiran Penelitian 


\section{Metode Pengumpulan Data}

Penelitian ini dilaksanakan di Kabupaten Kampar dan Kabupaten Rokan Hulu Provinsi Riau. Kabupaten Kampar secara geografis terletak antara 010 00’ 40” LU - $00^{\circ} 27^{\prime}$ 00” LS dan $100^{\circ}$ 28' 30"-1010 14' 30" BT. Luas wilayah Kabupaten Kampar sebesar 11.289,28 ha dan Kabupaten ini berbatasan dengan Kota Pekanbaru dan Kabupaten Siak di sebelah utara, Kabupaten Kuantan Singingi di sebelah selatan, Kabupaten Rokan Hulu dan 20” LU - $010^{\circ} 25^{\prime} 41^{\prime \prime}$ LU dan $100^{\circ} 02^{\prime}$ 56” BT - 100 56' 59” BT dan memiliki luas wilayah sebesar 746.218 ha. Kabupaten Rokan Hulu berbatasan dengan Sumatera Barat di sebelah selatan, Kabupaten Bengkalis di sebelah timur, serta Provinsi Sumatera Barat dan Provinsi Sumatera Utara di sebelah barat. Peta lokasi penelitian dapat di lihat pada gambar 2. Penelitian dilaksanakan selama delapan bulan terhitung mulai bulan September 2016 sampai bulan April 2017.

Data yang digunakan dalam penelitian ini berupa data primer dan data sekunder. Data primer didapatkan melalui survei lapangan dan wawancara menggunakan kuesioner terhadap para responden meliputi Dinas Peternakan dan Perkebunan Kabupaten Rokan Hulu, Dinas Perindustrian dan Perdagangan Kabupaten Rokan Hulu, BAPPEDA Kabupaten Rokan Hulu untuk memperoleh persepsi stakeholders mengenai arahan pengembangan agroindustri karet dalam peningkatan ekonomi wilayah di Kabupaten Rokan Hulu. Petani karet, pedagang pengumpul dan pedagang besar getah karet untuk mengetahui harga getah karet di Kabupaten Rokan Hulu.

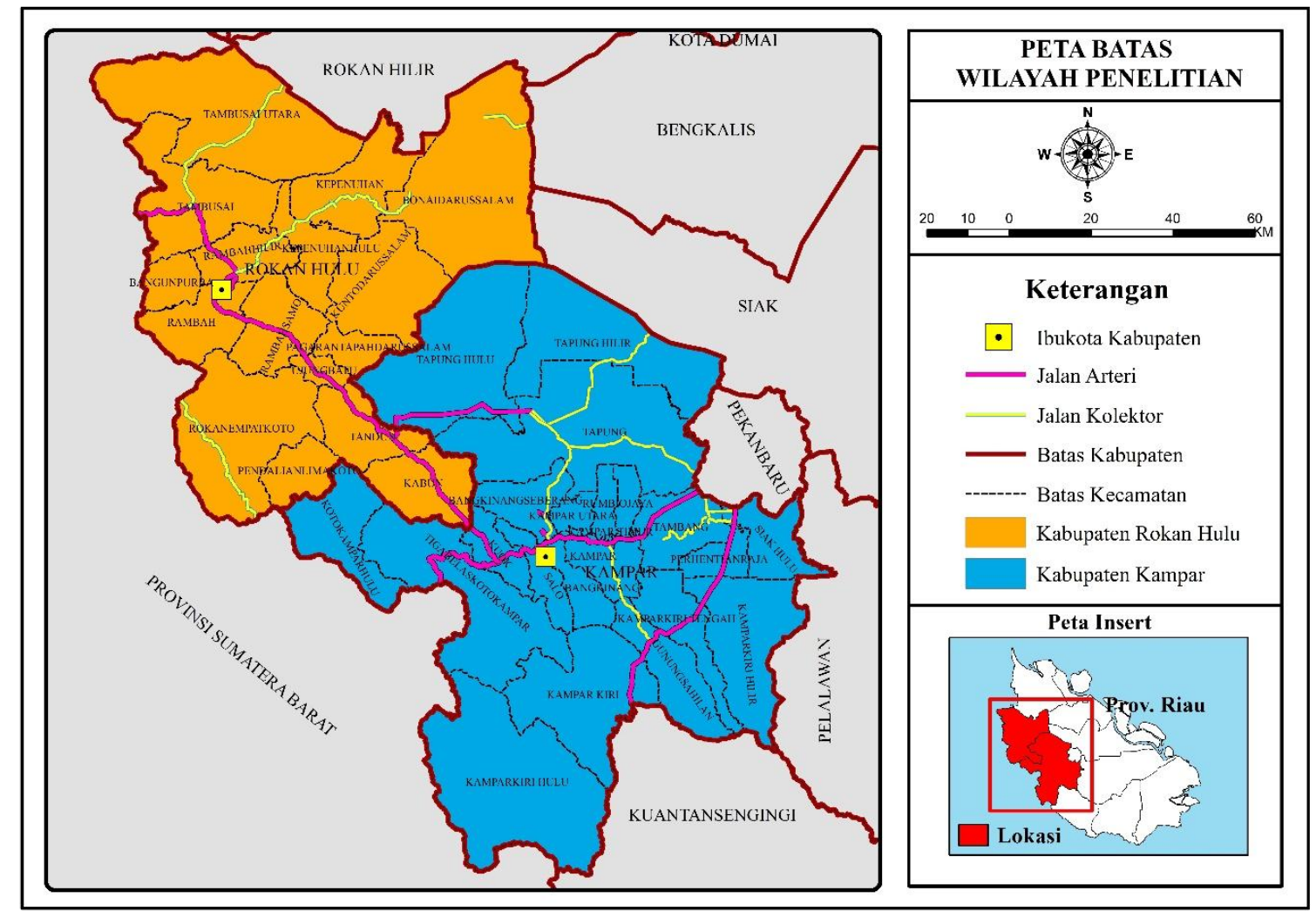

Gambar 2. Peta Lokasi Penelitian

Data sekunder berupa tabel input output Provinsi Riau 2010 dari BPS Provinsi Riau di update ke tabel input output Kabupaten Kampar 2015 dan tabel input output Kabupaten 
Rokan Hulu 2015, PDRB Kabupaten Kampar 2015 dan PDRB Kabupaten Rokan Hulu 2015. Alat yang digunakan dalam penelitian ini berupa komputer yang dilengkapi $M S$ Office 2013, MS Excel 2013, software expert choice 2000 serta alat tulis.

\section{Metode Analisis Data}

\section{Analisis Margin Pemasaran Getah Karet}

Pemilihan rantai pemasaran yang tepat sangat diperlukan agar arus barang dan jasa dari produsen ke konsumen dapat berjalan dengan baik. Pemilihan rantai pemasaran yang tepat sangat diperlukan agar arus barang dan jasa dari produsen ke konsumen dapat berjalan dengan baik. Hasil penelitian Ahmadi et al. (2016), pemasaran bokar yang terjadi di Desa Surya Adi Kecamatan Mesuji Kabupaten Ogan Komering Ilir belum terorganisir dengan baik disebabkan oleh rantai pemasaran yang panjang dan mutu bokar yang rendah.

Analisis margin pemasaran pada penelitian ini digunakan untuk menghitung selisih antara harga yang dibayarkan oleh konsumen dengan harga yang diterima oleh petani. Terdapat 4 Kecamatan di Kabupaten Rokan Hulu yang menjadi fokus dalam analisis margin pemasaran getah karet yaitu Kecamatan Rambah Samo, Kecamatan Rambah, Kecamatan Ujung Batu, dan Kecamatan Rambah Hilir. Pemilihan lokasi tersebut berdasarkan pertimbangan massifnya aktivitas perdagangan getah karet di wilayah tersebut.

Pengumpulan data dalam analisis ini didapatkan dari hasil wawancara menggunakan kuesioner dengan teknik purposive sampling yaitu subjek penelitian ditentukan berdasarkan pertimbangan tertentu misalnya orang tersebut dianggap paling tahu tentang apa yang kita harapkan atau mungkin dia sebagai penguasa sehingga memudahkan peneliti objek yang diteliti (Sugiyono 2008). Pada masing-masing kecamatan dipilih 2 orang responden yang mewakili petani karet, 2 orang responden mewakili pedagang pengumpul, dan 1 orang responden mewakili padagang besar.

Pada masing-masing kecamatan dipilih 2 orang responden yang mewakili petani karet, 2 orang responden mewakili pedagang pengumpul dan 1 orang responden mewakili padagang besar. Responden yang terpilih ini adalah orang-orang yang terlibat dan paham mengenai harga getah karet. Secara matematis besarnya margin pemasaran dihitung dengan formulasi (Sudiyono 2001), yaitu:

$$
\mathrm{MP}=\mathrm{Pr}-\mathrm{Pf}
$$

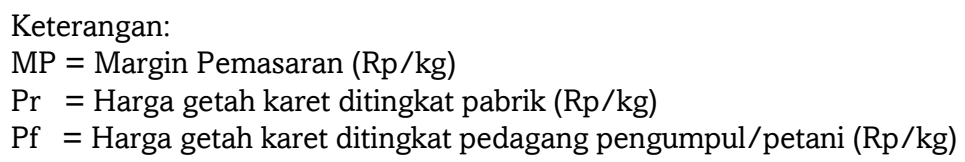

\section{Analisis Input-Output}

Karakteristik struktur ekonomi wilayah yang ditunjukkan dengan distribusi sumbangan sektoral serta keterkaitan sektoral perekonomian wilayah, secara teknis dapat dijelaskan dengan menggunakan analisis input output walaupun memiliki keterbatasan-keterbatasan tertentu (Rustiadi et al. 2011). Analisis input output menggunanakan tabel input output. Menurut Djakapermana (2010), tabel input output merupakan metode kuantitatif yang mampu menggambarkan tentang hubungan saling keterkaitan antar sektor ekonomi dalam suatu kegiatan perekonomian suatu wilayah 
secara menyeluruh pada satu tahun tertentu yang mencakup output dan nilai tambah masing-masing sektor.

Tabel input-output mempunyai keterbatasan yaitu koefisien input yang konstan selama periode analisis dan proyeksi sehingga teknologi yang digunakan oleh sektorsektor ekonomi dalam produksi juga dianggap konstan, biaya yang sangat tinggi untuk menyusun Tabel input-output dengan metode survei, dan semakin banyak agregasi yang dilakukan terhadap sektor-sektor maka akan semakin besar pula kecenderungan pelanggaran terhadap asumsi homogenitas dan akan semakin banyak informasi ekonomi yang tidak terungkap dalam analisis (Daryanto dan Hafizrianda 2010).

Analisis input output digunakan untuk melihat peran agroindustri karet dalam ekonomi wilayah di Kabupaten Kampar dan Kabupaten Rokan Hulu, berdasarkan data yang diturunkan dari tabel I-O Provinsi Riau. Analisis dilakukan mengacu pada tabel I-O Provinsi Riau tahun 2010 dengan 112 sektor perekonomian (112x112) yang di-update ke tahun 2015, kemudian diturunkan ke level kabupaten sehingga diperoleh tabel I-O Kabupaten Kampar dan Kabupaten Rokan Hulu dengan 15 sektor (15x15) yaitu sektor karet, kayu, karet remah dan karet asap, Bank, jasa perdagangan, bahan bangunan dari kayu, perabotan rumah tangga terbuat dari kayu, bambu dan rotan, ternak dan hasilhasilnya, barang-barang lainnya terbuat dari kayu, gabus bambu dan rotan, barangbarang plastik, alas kaki, cat, vernis dan lak, barang-barang industri lainnya, pakan ternak dan jasa angkutan darat.

Metode yang digunakan adalah metode RAS. Parameter teknis yang dapat diperoleh melalui analisis I-O adalah keterkaitan langsung ke belakang (direct backward linkage), keterkaitan langsung ke depan (direct forward linkage), keterkaitan ke belakang langsung dan tidak langsung (indirect backward linkage), keterkaitan ke depan langsung dan tidak langsung (indirect forward linkage). Prosedur RAS dapat dinyatakan dengan beberapa tahapan sebagai berikut:

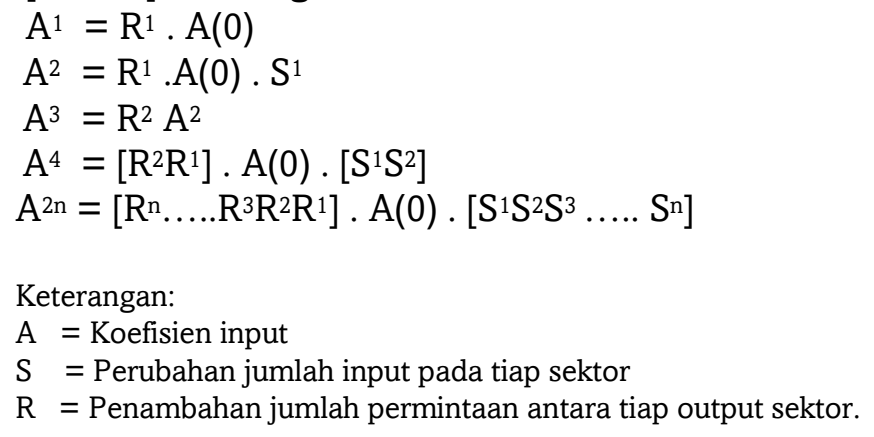

Perhitungan matriks koefisien input digunakan untuk mengetahui besarnya input yang dibutuhkan suatu sektor untuk menghasilkan output, baik input yang berasal dari sektor lain maupun sektor itu sendiri. Rumus yang digunakan sebagai berikut:

$$
a i j=\frac{\mathrm{zij}_{j}}{X_{j}}
$$

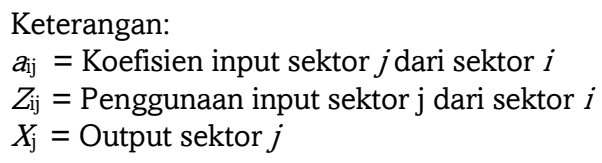

Matriks leontif invers digunakan untuk mengetahui angka pengganda yang menentukan besarnya perubahan sektor secara keseluruhan jika jumlah produksi suatu sektor berubah. Rumus matriks leontif invers, sebagai berikut:

$$
\mathrm{X}=(\mathrm{I}-\mathrm{A})^{-1} \mathrm{Y}
$$




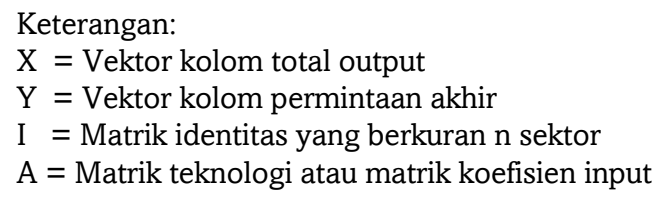

\section{Analisis Keterkaitan}

Analisis keterkaitan yang akan dianalisis yaitu keterkaitan ke belakang (backward linkage) dan keterkaitan ke depan (forward linkage). Dalam hal ini keterkaitan sektor ekonomi yang ingin di lihat yaitu antara sektor agroindustri karet dan sektor ekonomi lain yang ada di Kabupaten Kampar dan Kabupaten Rokan Hulu.

\section{Kaitan langsung ke belakang (direct backward linkage)}

Menunjukkan efek permintaan suatu sektor terhadap perubahan tingkat produksi sektor-sektor yang menyediakan input antara bagi sektor tersebut secara langsung. Rumus yang digunakan sebagai berikut:

$$
\mathbf{B}_{j}=\sum_{i}^{n} \alpha_{i j}
$$

Keterangan:

$\mathrm{B}_{j}=$ Keterkaitan langsung ke belakang dari sekto $j$

$a_{i j}=$ Koefisiean input dari sektor $j$ ke sektor $i$

Pengukuran normalized $\mathrm{B}_{j}$ merupakan rasio antar kaitan langsung ke belakang sektor $j$ dengan rata-rata backward linkage sektor-sektor lainnya. Rumus yang digunakan sebagai berikut:

$$
B_{j}=\frac{B_{j}}{\frac{1}{\mathrm{n}} \sum_{i} \sum_{j} B_{j}}=\frac{\mathrm{n} \cdot B_{j}}{\sum_{i} B_{j}}
$$

Nilai $\mathrm{B}_{j}$ di atas 1 menunjukkan bahwa sektor $j$ memiliki kaitan ke belakang yang kuat dalam pengertian memiliki pengaruh yang lebih kuat terhadap pertumbuhan pertumbuhan sektor-sektor lain dalam memenuhi derived demand (turunan permintaan) yang ditimbulkan oleh sektor ini.

\section{Kaitan langsung ke depan (direct forward linkage)}

Menunjukkan banyaknya output suatu sektor yang dipakai secara langsung oleh sektor-sektor lain. Rumus yang digunakan sebagai berikut:

$$
F_{i}=\sum_{j}^{n} \mathrm{a}_{i j}
$$

Keterangan:

$F_{i}=$ Keterkaitan langsung ke depan dari sekto $i$

$\mathrm{a}_{i j}=$ Koefisiean output dari sektor $i$ ke sektor $j$

Normalized $F_{i}$ atau $F_{j}$ dirumuskan sebagai berikut:

$$
F_{j}=\frac{F_{i}}{\frac{1}{\mathrm{n}} \sum_{i} F_{i}}=\frac{n F_{i}}{\sum F_{i}}
$$




\section{Kaitan ke belakang langsung dan tidak langsung (indirect backward linkage)}

Menunjukkan pengaruh tidak langsung dari kenaikan permintaan akhir satu unit sektor tertentu (j) yang dapat meningkatkan total output seluruh sektor perekonomian. Parameter ini menunjukkan kekuatan suatu sektor dalam mendorong peningkatan seluruh sektor perekonomian, dirumuskan sebagai berikut:

$$
\begin{aligned}
& B L_{j}=\sum_{i} \mathrm{~b}_{i j} \\
& \text { Keterangan: } \\
& b_{i j} \quad=\text { elemen-elemen matriks } B, \text { atau } \\
& (I-A)^{-1}=\text { invers matriks Leontief }
\end{aligned}
$$

\section{Kaitan ke depan langsung dan tidak langsung (indirect fordward linkage)}

Peranan suatu sektor (i) dapat memenuhi permintaan akhir dari seluruh sektor perekonomian. Dirumuskan sebagai berikut:

$$
F L_{i}=\sum_{j} \mathrm{~b}_{i j}
$$

Apabila permintaan akhir tiap sektor perekonomian meningkat satu unit (yang berarti peningkatan permintaan akhir seluruh sektor perekonomian adalah sebesar $n$ unit), dengan demikian makan sektor $i$ menyumbang pemenuhannya sebesar $F L_{i}$.

\section{Analisis Dampak Pengganda (Multiplier Impact)}

Multiplier adalah koefisien yang menyatakan kelipatan dampak langsung dan tidak langsung dari meningkatnya permintaan akhir suatu sektor sebesar satu unit terhadap aspek-aspek tertentu ekonomi suatu wilayah. Dalam penelitian ini efek multiplier yang akan dianalisis yaitu:

\section{Pengganda output (output multiplier)}

Penggandaan output dilakukan untuk menghitung dampak meningkatnya permintaan akhir suatu sektor terhadap total output seluruh sektor di wilayah penelitian. Rumus yang digunakan sebagai berikut:

$$
\mathrm{X}=(\mathrm{I}-\mathrm{A})^{-1} \cdot \mathrm{Fd}^{\mathrm{d}}
$$

$\mathrm{X}$ adalah matriks, maka matriks tersebut dapat merinci dampak permintaan akhir dari masing-masing sektor terhadap pembentukan output.

\section{Pengganda pendapatan (income multiplier)}

Pengganda pendapatan dilakukan untuk menghitung dampak meningkatnya permintaan akhir suatu sektor terhadap peningkatan pendapatan rumah tangga di wilayah penelitian secara keseluruhan. Rumus yang digunakan sebagai berikut:

$$
\mathrm{V}_{\mathrm{j}}=\mathrm{W}_{\mathrm{j}}+\mathrm{T}_{\mathrm{j}}
$$

Keterangan:

$\mathrm{V}_{\mathrm{j}}=$ Input primer sektor $j$

$\mathrm{W}_{\mathrm{j}}=$ Pendapatan rumah tangga sektor $j$

$\mathrm{T}_{\mathrm{j}}=$ Pendapatan perusahaan sektor $j$ 
Koefisien income $W_{j}$ adalah:

$$
\hat{\mathrm{W}} j=\frac{W j}{X i}
$$

Pengganda pendapatan (income multiplier) dapat dihitung dengan matriks:

$$
\begin{aligned}
& W=\hat{\mathrm{w}} X \\
& \text { Keterangan: } \\
& W=\text { Matriks income } \\
& \hat{\mathrm{W}}=\text { Matriks diagonal koefisien income } \\
& X=\text { Matriks output, } X=(I-A)^{-1} \cdot F^{d}
\end{aligned}
$$

\section{Pengganda NTB (NTB multiplier)}

Pengganda Nilai Tambah Bruto (NTB) atau PDRB adalah dampak meningkatnya permintaan akhir suatu sektor terhadap peningkatan PDRB. Dalam tabel I-O, diasumsikan NTB atau PDRB berhubungan dengan output secara linier yang dapat diasumsikan dengan persamaan matrik berikut:

$$
V=\hat{v} X
$$

Keterangan:

$V=$ Matrik NTB

$\hat{\mathrm{v}}=$ Matrik diagonal koefisien NTB

$X=$ Matriks output, $X=(I-A)^{-1} \cdot F^{d}$

$$
\begin{aligned}
\text { Karena } \hat{v}= & \frac{\mathrm{V}}{\mathrm{X}}=\frac{N T B}{\text { Output sektor } i} \\
& \frac{\text { NTB } j}{\text { Output sektor } i} \frac{\text { NTB } j}{X} \frac{\mathrm{Vi}}{\mathrm{Xi}}
\end{aligned}
$$

\section{AHP (Analytical Hierarchy Process)}

AHP banyak digunakan pada pengambilan keputusan untuk banyak kriteria perencanaan, alokasi sumber daya, dan penentuan prioritas dari strategi-strategi yang dimiliki dalam situasi konflik (Saaty 2008). Pengumpulan data dalam analisis ini didapatkan dari hasil wawancara terhadap responden. Respondennya terdiri dari Dinas Peternakan dan Perkebunan Kabupaten Rokan Hulu, Dinas Perindustrian dan Perdagangan Kabupaten Rokan Hulu, dan BAPPEDA Kabupaten Rokan Hulu. Para responden yang terpilih ini adalah orang-orang yang dianggap terlibat dan paham mengenai agroindustri karet.

Analisis AHP ini menggunakan software expert choice 2000 dengan tahapantahapan pengambilan keputusan kebijakan, yaitu:

1) Penentuan tujuan, kriteria dan subkriteria, serta alternatif yang kemudian disusun dalam sebuah hirarki.

a. Level 1 dalam hirarki yang dibangun merupakan fokus/tujuan yang ingin dicapai yaitu pengembangan agroindustri karet di Kabupaten Rokan Hulu.

b. Level II merupakan kriteria yang digunakan meliputi subsistem agribisnis hulu, sub sistem agribisnis on farm, sub sistem agribisnis hilir, dan sub sistem agribisnis layanan penunjang. Strategi pembangunan sistem agribisnis diyakini mampu mengantarkan perekonomian Indonesia memiliki daya saing dan bersinergis dalam perekonomian dunia (Antara, 2001). Hal ini sejalan dengan pendapat Syafa'at \& Mardianto (2011), menyatakan pengembangan sektor pertanian harus 
diletakkan dalam kerangka pengembangan sistem agribisnis, sehingga sektor pertanian mampu menjadi sektor andalan ekonomi nasional.

c. Level III merupakan subkriteria yang digunakan meliputi bahan baku, modal, teknologi, pasar, sumberdaya manusia, dan sarana prasarana.

d. Level IV merupakan alternatif pilihan yang dapat digunakan dalam menentukan level industri yang dapat diterapkan pada lokasi penelitian, alternatif tersebut berdasarkan Peraturan Menteri Perindustrian Nomor 112/M IND/PER/10/2009 yang mengelompokkan industri karet dan barang karet menjadi tiga kelompok, yaitu: 1) kelompok industri hulu; 2) kelompok industri antara; 3) dan kelompok industri hilir. Namun pada penelitian ini hanya menggunakan kelompok industri hulu dan industri antara.

Pemilihan kriteria, subkriteria, dan altrenatif pada penelitian ini adalah hal-hal yang dianggap substansial dan sesuai dengan kondisi lapangan sebagai tahap awal pengembangan agroindustri karet di Kabupaten Rokan Hulu. Selengkapnya dapat dilihat pada Gambar 3.

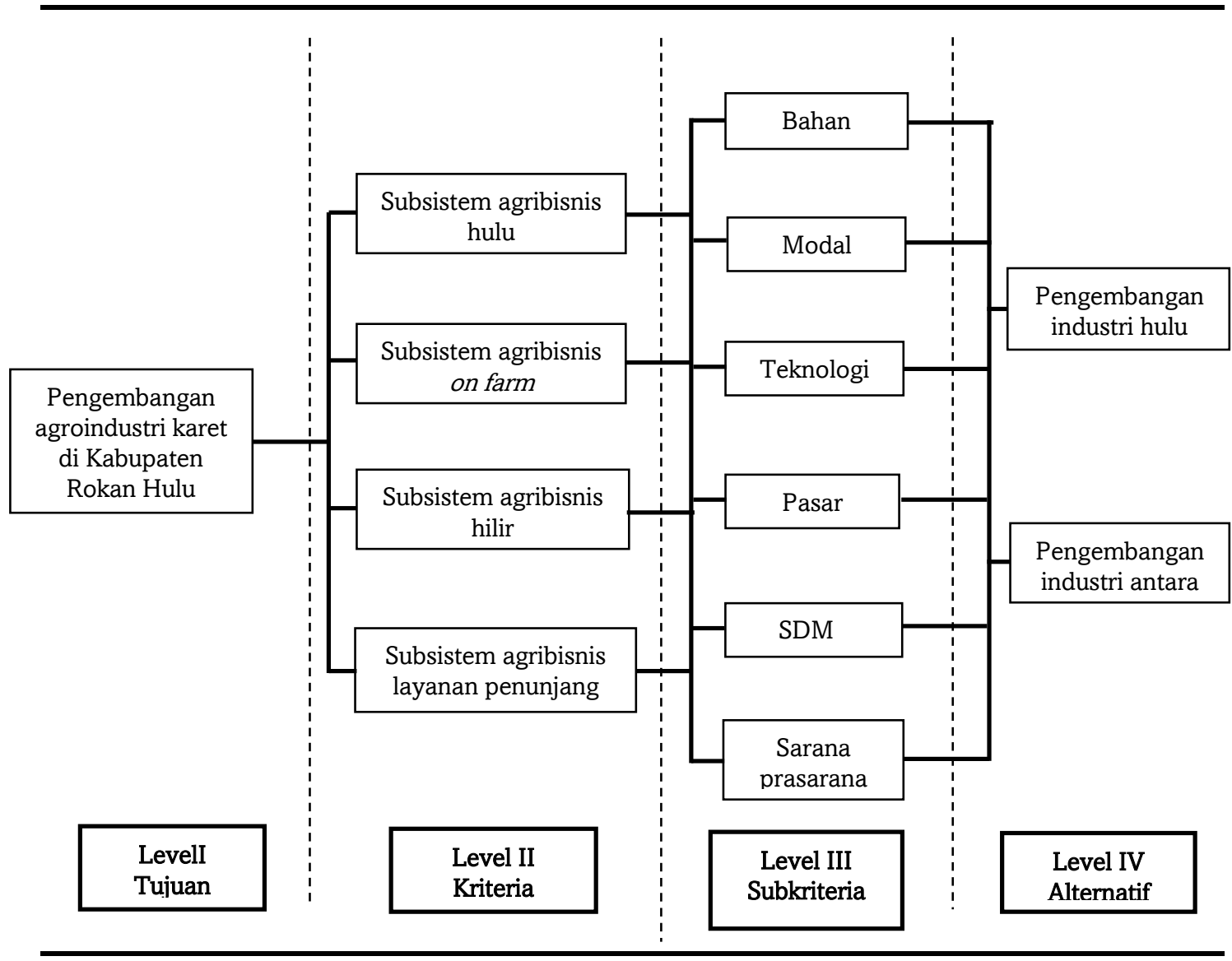

Gambar 3. Struktur Hirarkhi AHP Penentuan Pengembangan Agroindustri Karet

2) Pembobotan terhadap kriteria dengan perbandingan berpasangan (pairwise comparison). Ini dilakukan untuk setiap tingkat dalam struktur hirarki, bobot yang digunakan adalah skala komparasi yang efektif adalah 1 sampai 9 (Saaty 1996). Nilai bobot menggambarkan tingkat kepentingan masing-masing kriteria, yaitu nilai 1 menggambarkan bahwa dua kriteria yang dibandingkan memiliki tingkat kepentingan yang sama, sedangkan nilai 9 memiliki tingkat kepentingan yang mutlak (Tabel 1). 
Tabel 1. Skala Komparasi Antar Elemen

\begin{tabular}{cl}
\hline Nilai & \multicolumn{1}{c}{ Keterangan } \\
\hline 1 & Sama penting antara dua elemen \\
5 & Sedikit lebih penting dari elemen pasangannya \\
7 & Jelas lebih penting dari elemen pasangannya \\
9 & Sangat jelas lebih penting dari elemen pasangannya \\
$2,4,6,8$ & Mutlak lebih penting dari elemen pasangannya \\
\hline
\end{tabular}

Sumber: Saaty (1996).

3) Setelah bobot kriteria didapatkan, lakukan pengecekan konsistensi untuk matrik perbandingan berpasangan. Jika lebih dari 0.1 maka harus dilakukan perbandingan berpasangan kembali sampai didapat ratio kurang dari atau sama dengan 0.1 . Lakukan juga hal tersebut pada masing-masing matrik perbandingan antara alternatif.

4) Hitung total dari perkalian antara bobot kriteria dengan bobot alternatif yang bersesuaian.

\section{HASIL DAN PEMBAHASAN}

\section{Pemasaran Getah Karet di Kabupaten Rokan Hulu}

Terdapat 3 saluran pemasaran getah karet di Kabupaten Rokan Hulu mulai dari petani hingga di tingkat pabrik pengolahan getah karet. Beberapa lembaga pemasaran yang terlibat dalam pemasaran getah karet yaitu petani sebagai produsen getah karet, pedagang pengumpul, dan pedagang besar. Hasil analisis ini sama seperti hasil penelitian Wahyudy HA et al. (2015) menyatakan sistem pemasaran getah karet di Kabupaten Kuantan Singingi juga terdiri dari tiga saluran pemasaran. Temuan ini berbeda dengan hasil penelitian Tety $\mathrm{E}$ et al. ( 2014), menyatakan bahwa di Desa Sei Tonang Kecamatan Kampar Utara Kabupaten Kampar hanya terdapat satu saluran pemasaran bokar pada petani karet atau bersifat homogen. Skema rantai pemasaran getah karet dapat dilihat pada Gambar 4.

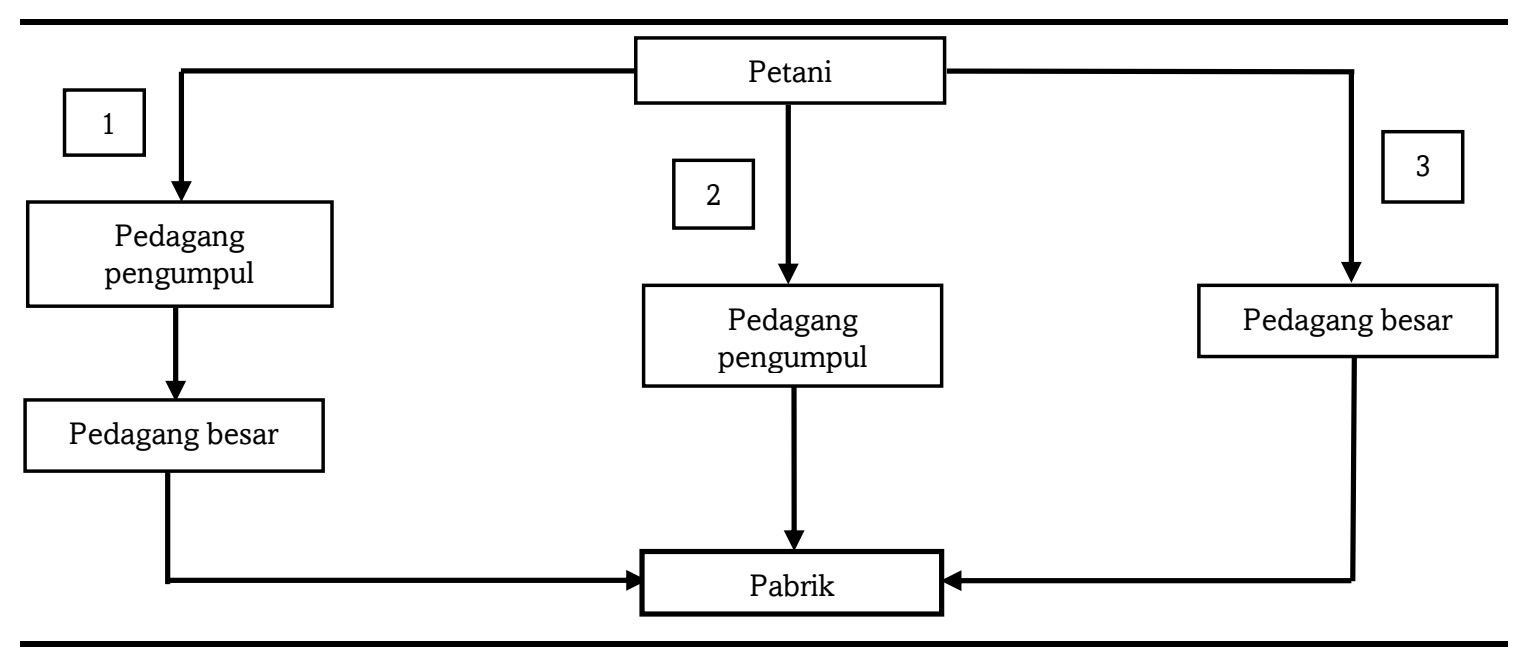

Gambar 4. Rantai Pemasaran Getah Karet di Kabupaten Rokan Hulu

Pabrik karet yang menjadi tujuan penjualan getah karet di Kabupaten Rokan yaitu 1). Kota Padang adalah PT. Lembah Karet dan PT. Teluk Luas memproduksi crumb rubber 
Sir 20, dan 2). Kota Pekanbaru adalah PT. Rekri dan PT. Union Siak juga memproduksi crumb rubber. Hal tersebut disebabkan selain karena belum adanya pabrik karet di Kabupaten Rokan Hulu, juga karena harga beli dari pabrik-pabrik yang terdapat di kota tersebut relatif tinggi. Harga jual petani pada pemasaran saluran I kisaran Rp8.000$9.000 / \mathrm{kg}$, pemasaran saluran II kisaran Rp9.000-10.500/kg dan pemasaran saluran III kisaran Rp9.500-10.800/kg. Penetapan harga dilihat dari kualitas getah karet secara visual, yaitu kebersihan dan kesegaran getah karet, serta kadar air yang terkandung di dalamnya. Prosesnya manual, hanya berdasarkan pengalaman pribadi pedagang pengumpul. Apabila terdapat ketidaksesuaian dari besarnya bongkahan getah karet dengan berat getah karet tersebut, maka akan dilakukan cek kualitas getah karet dengan cara membelah dua getah karet tersebut. Harga getah karet ditentukan berdasarkan kualitas getah karet yang dihasilkan sehingga petani harus mengusahakan getah karet yang berkualitas baik agar harganya lebih tinggi. Hasil penelitian Napitupulu (2011), menyatakan bahwa pada dasarnya terdapat hubungan yang nyata antara kualitas bokar yang diperdagangkan dengan harga yang diterima oleh petani. Hal ini seyogyanya petani menghasilkan bokar mutu baik agar pendapatan mereka dapat lebih tinggi.

Pedagang pengumpul dan pedagang besar memiliki biaya pemasaran seperti upah tenaga kerja, transportasi dan penyusutan berat timbangan (10\%). Tindakan antisipasi terhadap penyusutan berat timbang dibebankan $1 \mathrm{~kg}$ dalam setiap $10 \mathrm{~kg}$ getah karet. Harga jual pedagang pengumpul dan pedagang besar yang menjual langsung getah karet ke pabrik karet kisaran Rp12.500-13.000/kg. Harga karet ditentukan berdasarkan kemurnian karet. Untuk mengetahui kemurnian karet itu, pihak pabrik melakukan uji laboratorium berdasarkan sampel dan biasanya hasil pengujian menunjukkan bahwa rata-rata kemurnian karet yang diterima hanya mencapai 60\%. Ketetapan kadar ini berlaku umum, padahal tidak semua produksi getah karet rakyat memiliki tingkat kadar kemurnian karet yang sama.

Pada tabel 2, besarnya biaya pada setiap saluran ditentukan dari harga rata-rata penjualan getah karet. Margin pada saluran pemasaran I oleh pedagang pengumpul sebesar Rp2.000, pedagang besar sebesar Rp.2000 total margin pemasaran sebesar Rp4.000. Margin pada saluran pemasaran II sebesar Rp2.750 dan saluran pemasaran III sebesar Rp2.850. Menurut Daniel (2002), makin panjang pemasaran (semakin banyak lembaga yang terlibat) maka semakin besar margin pemasaran, hal ini sejalan dengan hasil pengolahan pada pemasaran saluran I.

Tabel 2. Margin Pemasaran Getah Karet (Per kg)

\begin{tabular}{|c|c|c|c|c|c|c|}
\hline \multirow[b]{2}{*}{ Uraian } & \multicolumn{3}{|c|}{ Saluran I } & \multirow{2}{*}{$\begin{array}{r}\text { Saluran II } \\
\text { Share } \\
(\%)\end{array}$} & \multicolumn{2}{|c|}{ Saluran III } \\
\hline & $\begin{array}{c}\text { Biaya } \\
\text { (Rp) }\end{array}$ & $\begin{array}{c}\text { Share } \\
(\%)\end{array}$ & $\begin{array}{c}\text { Biaya } \\
\text { (Rp) }\end{array}$ & & $\begin{array}{c}\text { Biaya } \\
\text { (Rp) }\end{array}$ & $\begin{array}{c}\text { Share } \\
(\%)\end{array}$ \\
\hline \multicolumn{7}{|l|}{ Petani } \\
\hline Harga jual & 8.500 & 68 & 9.750 & 78 & 10.150 & 8,1 \\
\hline \multicolumn{7}{|l|}{ Pedagang pengumpul } \\
\hline Harga beli & 8.500 & & 9.750 & & & \\
\hline \multicolumn{7}{|l|}{ Biaya pemasaran } \\
\hline A. Upah tenaga kerja & 100 & & 200 & & & \\
\hline B. Transportasi & 200 & & 400 & & & \\
\hline C. Penyusutan berat timbangan $(10 \%)$ & 850 & & 975 & & & \\
\hline Total biaya pemasaran & 1.150 & 9,2 & 1.575 & 12,6 & & \\
\hline Keuntungan & 850 & 6,8 & 1.175 & 9,4 & & \\
\hline Margin & 2.000 & & 2.750 & & & \\
\hline Harga jual & 10.500 & & 12.500 & & & \\
\hline \multicolumn{7}{|l|}{ Pedagang besar } \\
\hline Harga beli & 10.500 & & & & & \\
\hline \multicolumn{7}{|l|}{ Biaya pemasaran } \\
\hline A. Upah tenaga kerja & 200 & & & & 200 & \\
\hline
\end{tabular}




\begin{tabular}{|c|c|c|c|c|c|c|}
\hline \multirow[b]{2}{*}{ Uraian } & \multicolumn{3}{|c|}{ Saluran I } & \multirow{2}{*}{$\begin{array}{c}\text { Saluran II } \\
\text { Share } \\
(\%)\end{array}$} & \multicolumn{2}{|c|}{ Saluran III } \\
\hline & $\begin{array}{l}\text { Biaya } \\
\text { (Rp) }\end{array}$ & $\begin{array}{c}\text { Share } \\
(\%)\end{array}$ & $\begin{array}{c}\text { Biaya } \\
\text { (Rp) }\end{array}$ & & $\begin{array}{c}\text { Biaya } \\
\text { (Rp) }\end{array}$ & $\begin{array}{c}\text { Share } \\
(\%)\end{array}$ \\
\hline B. Transportasi & 400 & & & & 400 & \\
\hline C. Penyusutan berat timbangan $(10 \%)$ & 1.050 & & & & 1.015 & \\
\hline Total biaya pemasaran & 1.650 & 13,2 & & & 1.615 & 12,4 \\
\hline Keuntungan & 350 & 2,8 & & & 1.235 & 9,5 \\
\hline Margin & 2.000 & & & & 2.850 & \\
\hline Harga jual & 12.500 & & & & 13.000 & \\
\hline Pabrik karet & & & & & & \\
\hline Harga beli & 12.500 & 100 & 12.500 & 100 & 13.000 & 100 \\
\hline Margin pemasaran & 4.000 & & 2.750 & & 2.850 & \\
\hline
\end{tabular}

Sumber: Data diolah (2017)

Berdasarkan rantai pemasaran getah karet yang terbentuk di masyarakat Kabupaten Rokan Hulu, maka saluran II dan III dianggap saluran yang paling menguntungkan petani karet. Saluran II merupakan saluran pemasaran paling efisien karena rendahnya margin pemasaran, sedangkan saluran III sangat menguntungkan petani dari segi harga jual getah karet yang tinggi dibandingkan dengan semua harga jual pada saluran lainnya. Hal ini dikarenakan semakin pendek rantai pemasaran getah karet ke konsumen, maka semakin banyak keuntungan yang akan diterima oleh petani karet. Menurut Agustian dan Mayrowani (2008), permasalahan yang cukup sering dihadapi oleh para pelaku (petani) yaitu tingginya biaya pemasaran dan pembagian balas jasa yang bersifat asimetris. Tingginya biaya pemasaran didukung oleh ketidakefisienan yang disebabkan panjangnya rantai pemasaran.

\section{Peran Agroindustri Karet dalam Perekonomian Wilayah di Kabupaten Kampar dan Kabupaten Rokan Hulu}

\section{Kaitan langsung ke depan (DFL) dan kaitan ke depan langsung dan tidak langsung (IFL)}

Hasil analisis di Kabupaten Kampar menunjukkan indeks DFL sektor karet remah dan karet asap sebesar 3,06 dan indeks IFL sebesar 1,23. Kaitan langsung ke depan dan kaitan ke depan langsung dan tidak langsung sektor karet remah dan karet asap dengan sektor perekonomian lainnya relatif besar (DFL dan IFL >1) (Gambar 5 dan 6).

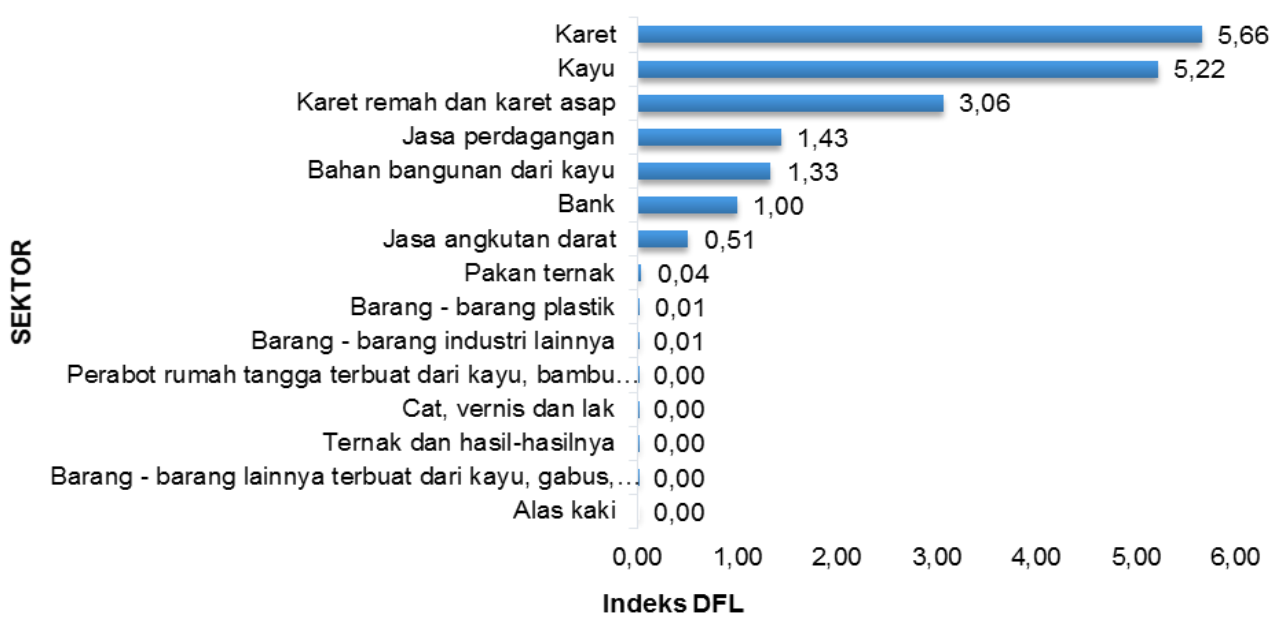

Gambar 5. Kaitan Langsung ke Depan (DFL) Sektor Karet Remah dan Karet Asap di Kabupaten Kampar Tahun 2015 


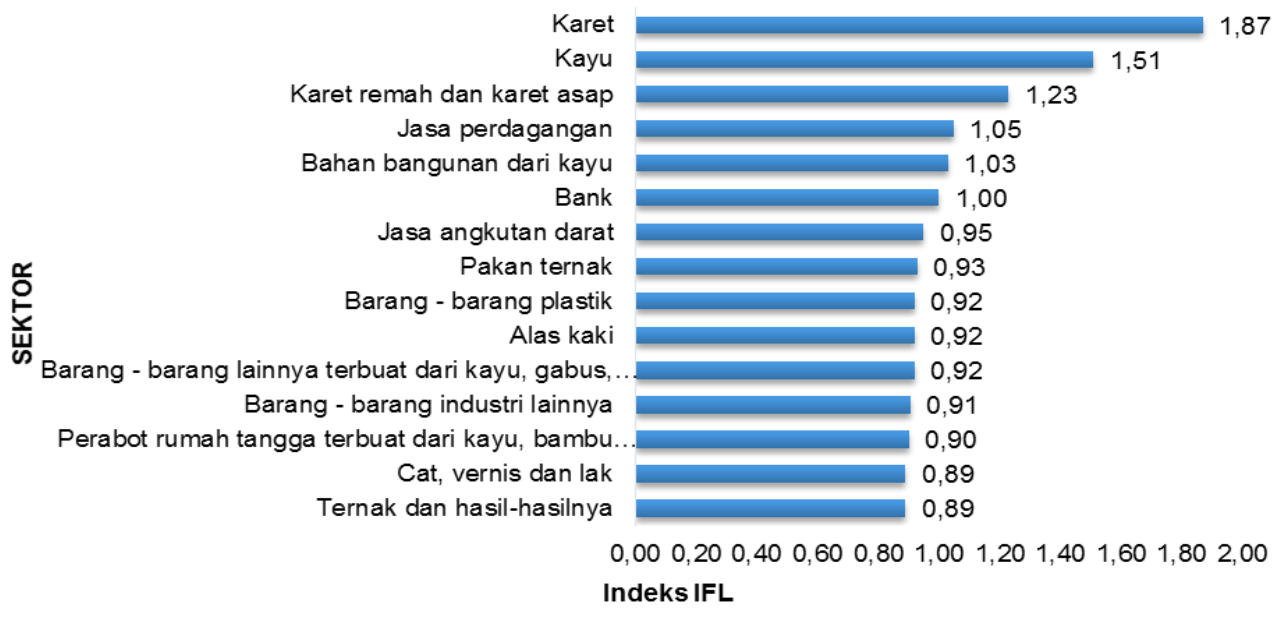

Gambar 6. Kaitan ke Depan Langsung dan Tidak Langsung (IFL) Sektor Karet Remah dan Karet Asap di Kabupaten Kampar Tahun 2015

Gambaran di Kabupaten Rokan Hulu juga relatif besar yaitu indeks DFL sebesar 3,21 dan IFL sebesar 1,24 (Gambar 7 dan 8).

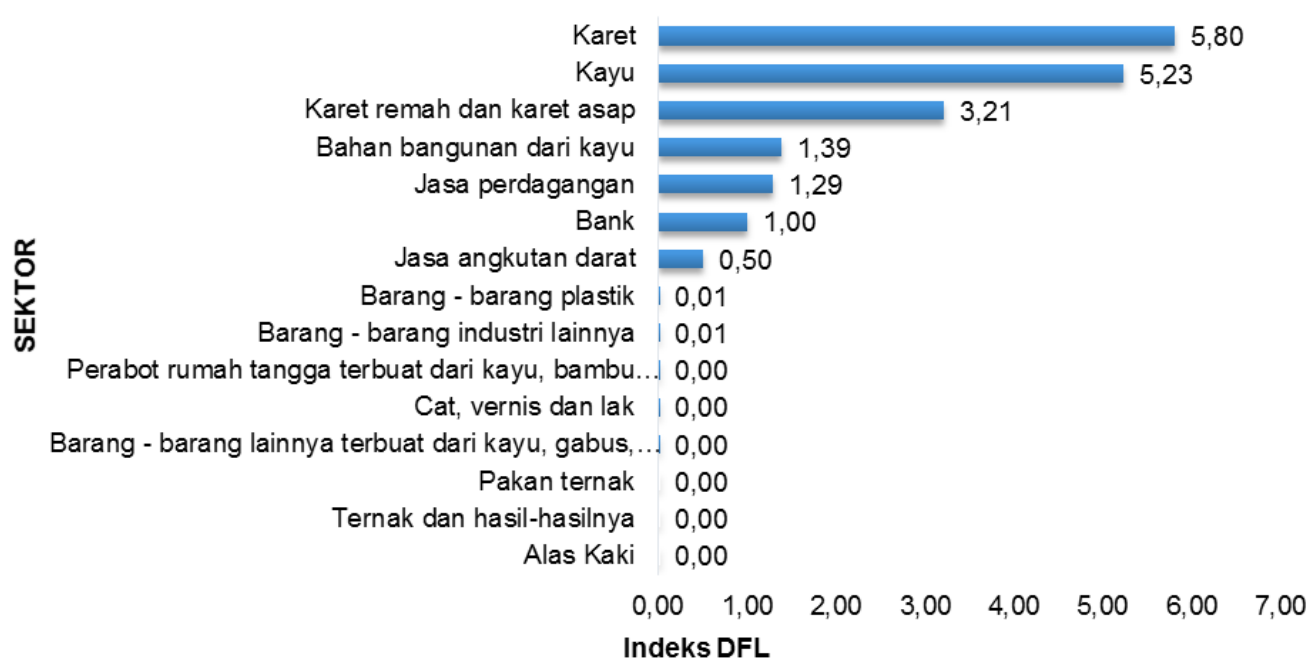

Gambar 7. Kaitan Langsung ke Depan (DFL) Sektor Karet Remah dan Karet Asap di Kabupaten Rokan Hulu Tahun 2015 


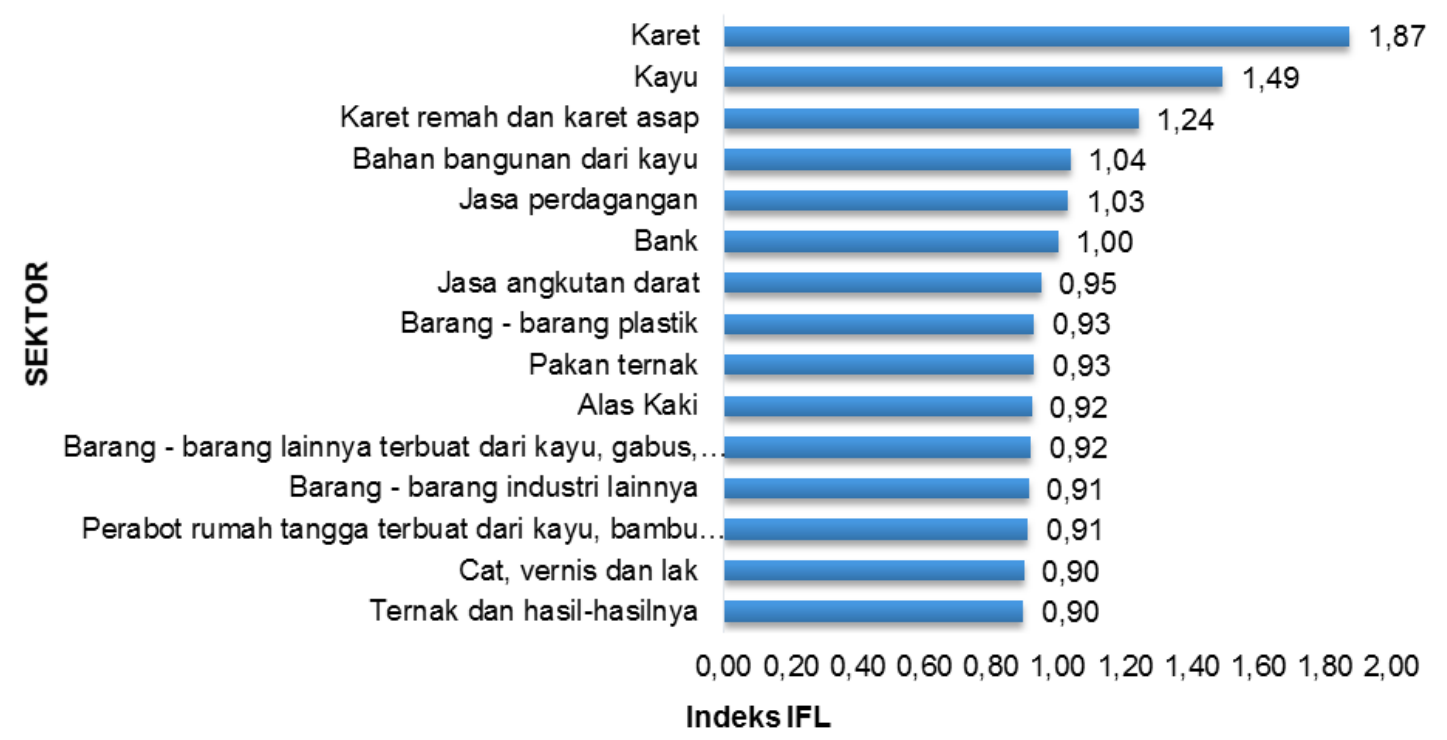

\section{Gambar 8. Kaitan ke Depan Langsung dan Tidak Langsung (IFL) Sektor Karet Remah dan Karet Asap di} Kabupaten Rokan Hulu Tahun 2015

Kaitan langsung ke belakang (DBL) dan kaitan ke belakang langsung dan tidak langsung (IBL)

Sektor karet remah dan karet asap di Kabupaten Kampar memiliki nilai indeks DBL sebesar 1,93 dan indeks IBL sebesar 1,15. Hasil kaitan langsung ke belakang dan kaitan ke belakang langsung dan tidak langsung sektor karet remah dan karet asap ini dengan sektor perekonomian lainnya relatif besar (DBL dan IBL >1) (Gambar 9 dan 10).

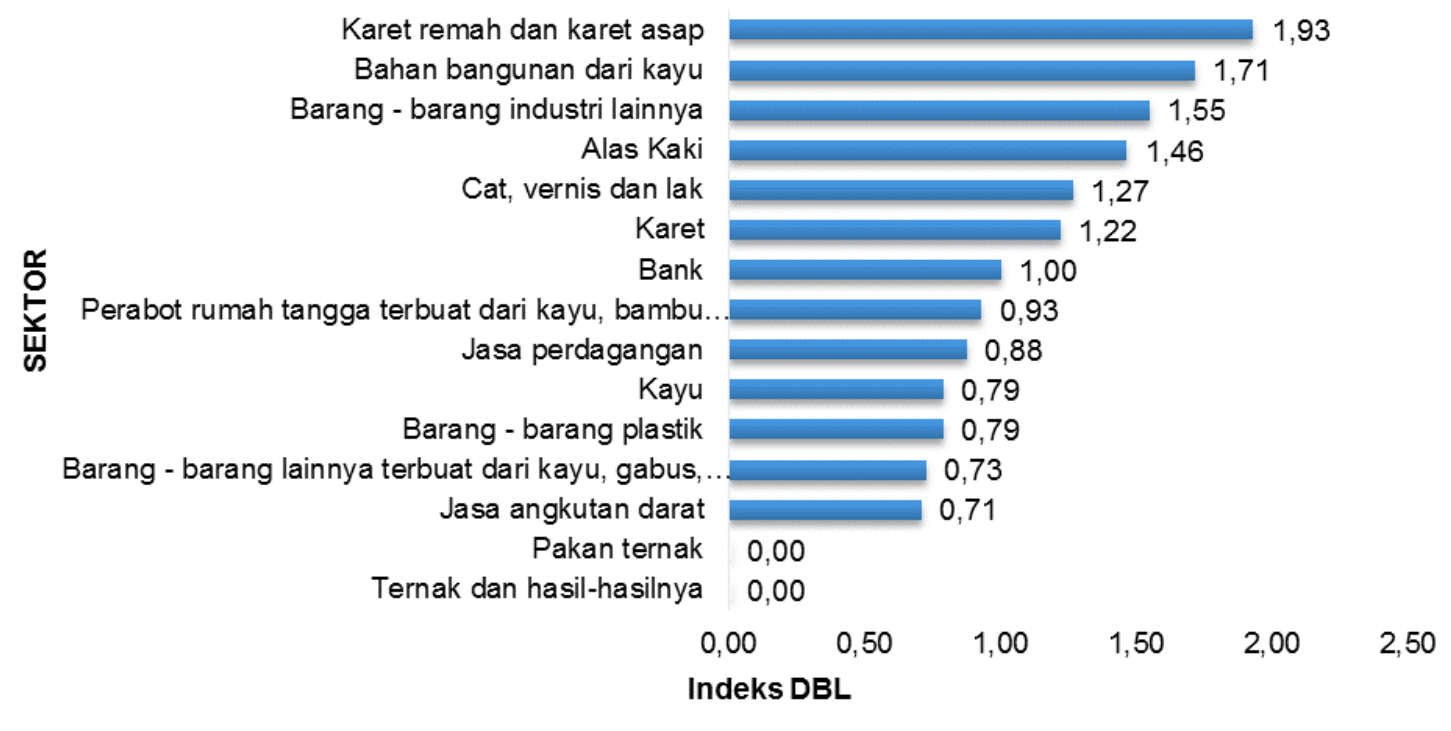

Gambar 9. Kaitan Langsung ke Belakang (DBL) Sektor Karet Remah dan Karet Asap di Kabupaten Kampar Tahun 2015 


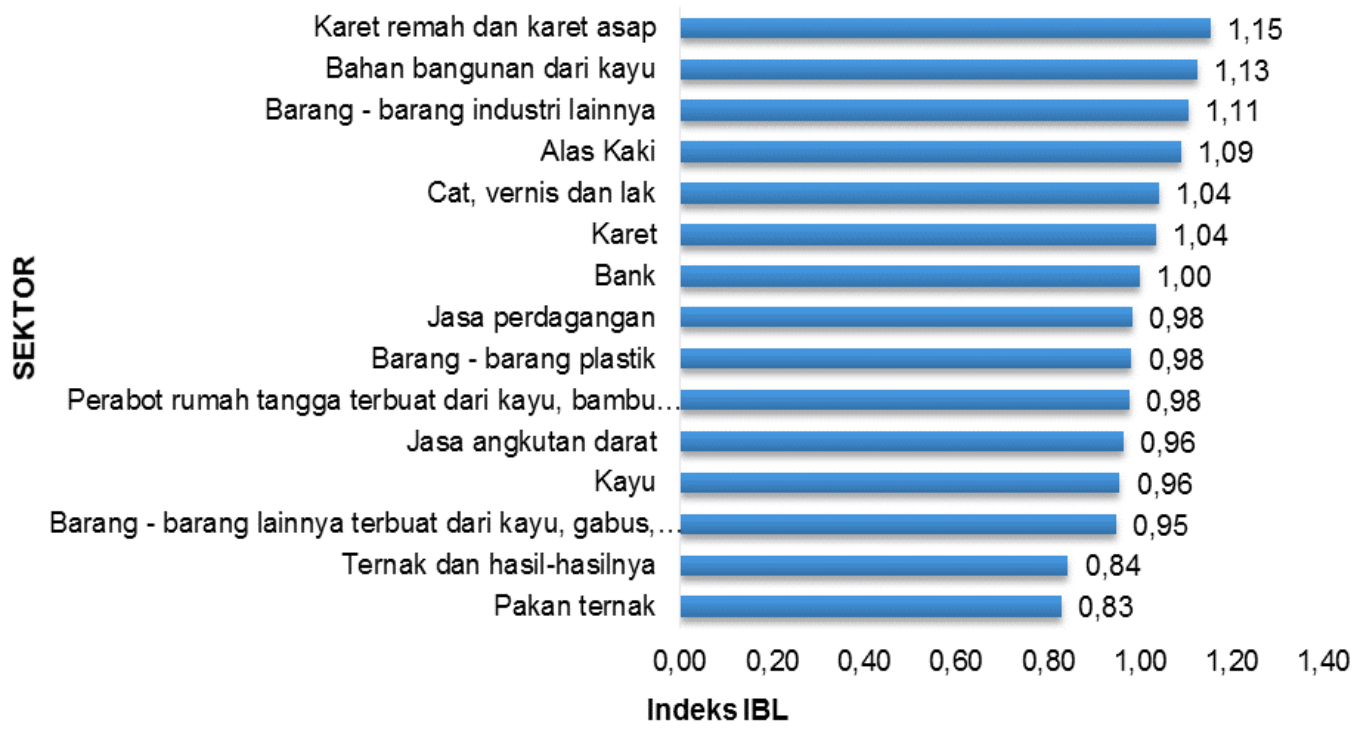

\section{Gambar 10. Kaitan ke Belakang Langsung dan Tidak Langsung (IBL) Sektor Karet Remah dan Karet} Asap di Kabupaten Kampar Tahun 2015

Gambaran hasil analisis DBL dan IBL sektor karet remah dan karet asap di Kabupaten Rokan Hulu juga relatif besar yaitu indeks DBL sebesar 1,93 dan indeks IBL sebesar 1,15 (Gambar 11 dan 12).

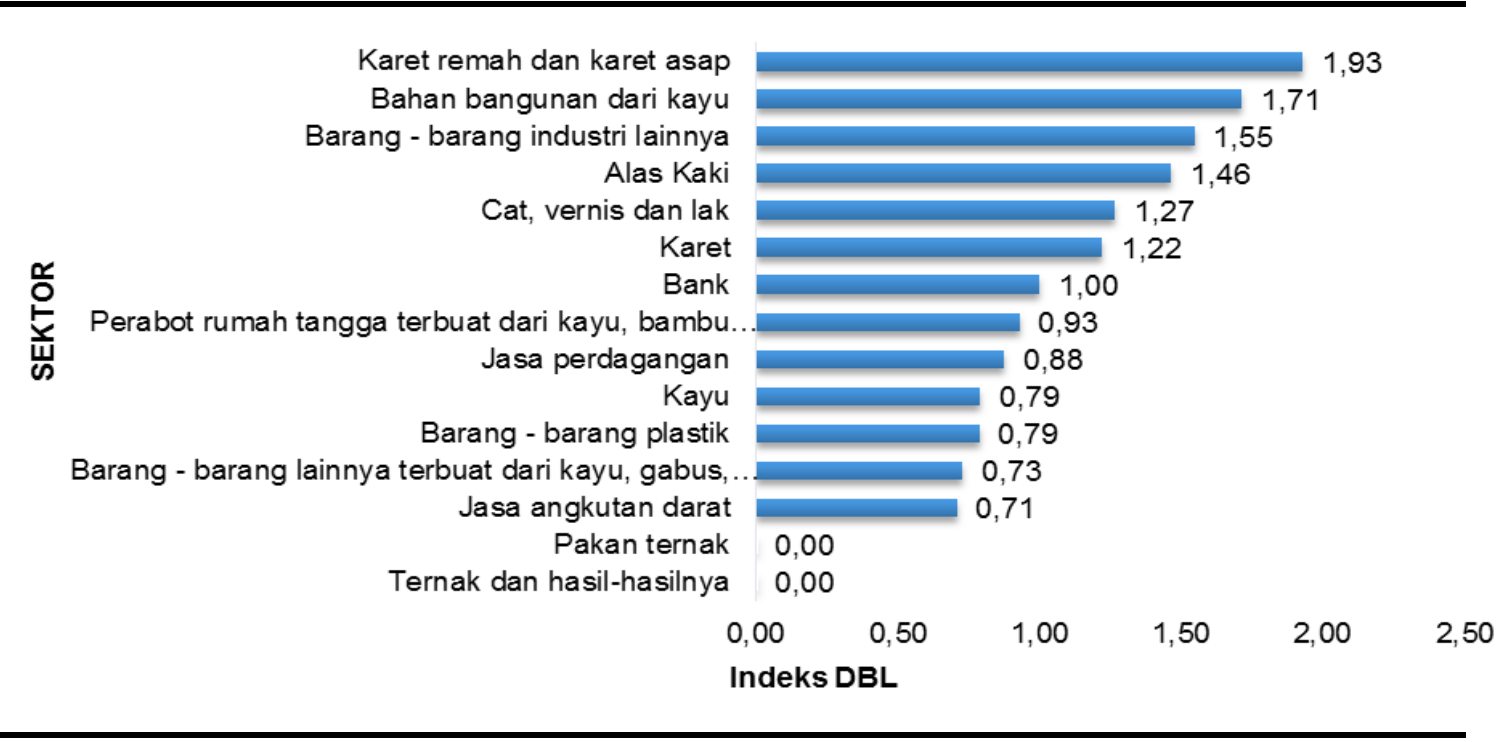

Gambar 11. Kaitan Langsung ke Belakang (DBL) Sektor Karet Remah dan Karet Asap di Kabupaten Rokan Hulu Tahun 2015 


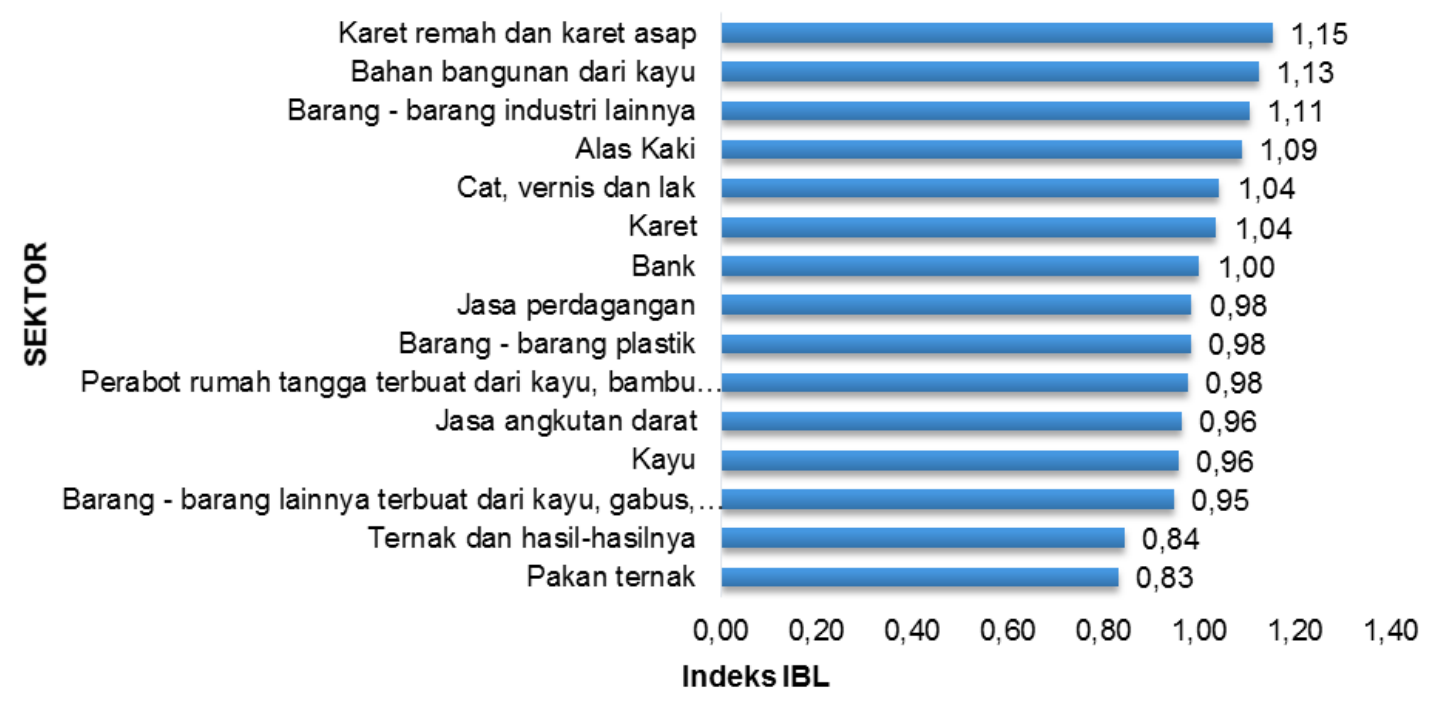

\section{Gambar 12. Kaitan ke Belakang Langsung dan Tidak Langsung (IBL) Sektor Karet Remah dan Karet Asap di Kabupaten Rokan Hulu Tahun 2015}

Menurut Tarigan (2010), setiap sektor memiliki keterkaitan yang cukup kuat karena keterkaitannya yang begitu luas, perubahan salah satu sektor akan memberi dampak pada sektor lainnya. Kemampuan sektor industri karet remah dan karet asap di Kabupaten Kampar dan Kabupaten Rokan Hulu memiliki kemampuan cukup tinggi dalam mendorong dan menarik pertumbuhan sektor-sektor lainnya, yang ditunjukkan dari kuatnya keterkaitan antara sektor industri karet dengan pertumbuhan sektor-sektor ekonomi lainnya (DFL, IFL >1) dan (DBL, IBL >1) sehingga dapat memicu peningkatan produksi dari sektor-sektor tersebut.

\section{Dampak kenaikan permintaan akhir (multiplier effect) terhadap kegiatan industri karet}

Dampak peningkatan permintaan akhir menyatakan kelipatan dampak langsung maupun tidak langsung dari meningkatnya permintaan akhir suatu sektor sebesar 1 miliar rupiah terhadap aspek ekonomi (output, pendapatan dan NTB). Dampak permintaan akhir kegiatan industri karet dapat dilihat pada Tabel 3.

Tabel 3. Multiplier Effect pada Kegiatan Sektor Karet Remah dan Karet Asap

\begin{tabular}{ccccccc}
\hline \multirow{2}{*}{ Sektor } & \multicolumn{3}{c}{ Multiplier Effect } \\
\cline { 2 - 7 } & \multicolumn{3}{c}{ Kabupaten Kampar } & \multicolumn{3}{c}{ Kabupaten Rokan Hulu } \\
\hline $\begin{array}{c}\text { Karet remah } \\
\text { dan karet asap }\end{array}$ & $\begin{array}{c}\text { Multiplier } \\
\text { Output }\end{array}$ & $\begin{array}{c}\text { Multiplier } \\
\text { Pendapatan }\end{array}$ & $\begin{array}{c}\text { Multiplier } \\
\text { NTB }\end{array}$ & $\begin{array}{c}\text { Multiplier } \\
\text { Output }\end{array}$ & $\begin{array}{c}\text { Multiplier } \\
\text { Pendapatan }\end{array}$ & $\begin{array}{c}\text { Multiplier } \\
\text { NTB }\end{array}$ \\
\cline { 2 - 7 } & 1,40 & 1,25 & 0,28 & 1,40 & 1,25 & $\begin{array}{c}0,2 \\
8\end{array}$ \\
\hline
\end{tabular}

Sumber: Data diolah (2017)

Berdasarkan tabel 3, Kabupaten Kampar dan di Kabupaten Rokan Hulu memiliki nilai multiplier output, multiplier pendapatan, dan multiplier NTB sektor karet remah dan karet asap yang sama. Nilai multiplier output sebesar 1,40, nilai tersebut menunjukkan bahwa jika terjadi peningkatan permintaan akhir pada sektor karet remah dan asap sebesar 1 miliar rupiah, maka dampak terhadap perekonomian (output) wilayah akan meningkat 
sebesar 1,40 miliar rupiah. Nilai multiplier pendapatan sebesar 1,25 dapat diartikan jika terjadi peningkatan permintaan akhir pada sektor karet remah dan karet asap sebesar 1 miliar rupiah, maka akan meningkatkan pendapatan rumah tangga di seluruh sektor dalam perekonomian sebesar 1,25 miliar rupiah. Nilai multiplier NTB sebesar 0,28 yang berarti dampak peningkatan sektor karet remah dan karet asap terhadap NTB akan meningkatkan 280 juta rupiah. Hubungan antara NTB dengan output bersifat linier, sehingga peningkatan atau penurunan output akan diikuti secara proporsional oleh kenaikan dan penurunan NTB (Hidayat et al. 2014).

\section{Arahan Pengembangan Agroindustri Karet di Kabupaten Rokan Hulu}

Alternatif pengembangan agroindustri di Kabupaten Rokan Hulu berdasarkan persepsi stakeholder mengarah pada subsistem agribisnis hilir dengan melakukan pengembangan agroindustri karet (skor 0,452). Pembangunan sistem dan usaha agribisnis termasuk pertanian di dalamnya, memiliki posisi tetap dan peranan yang sangat strategis dan mendasar dalam pembangunan ekonomi nasional karena hamparan wilayah Indonesia yang berbasiskan pertanian (Krisnamurthi et al. 2010). Pernyataan ini sangat sesuai dengan target pemerintah saat ini untuk menjadikan Kabupaten Rokan Hulu sebagai sentra produksi karet terbesar pada tahun 2020. Pemerintah telah mengupayakan membuka peluang investasi untuk industri pengolahan hasil tanaman karet.

Faktor utama yang menjadi penentu kegiatan industri pengolahan karet di Kabupaten Rokan Hulu menurut persepsi stakeholder dalam pengelolaan dibutuhkan sumber daya manusia yang berkualitas, trampil dan handal (skor 0,319), dengan begitu kelembagaan agroindustri dapat berjalan sesuai dengan visi dan misi perusahaan, sehingga perusahaan dapat berkembang mengikuti perkembangan pasar. Hal ini sejalan dengan pendapat Sari FP (2009) yang menyatakan bahwa percepatan pengembangan agroindustri dapat dilakukan dengan mengembangkan kualitas sumber daya manusia unggulan daerah yang mencakup peningkatan keahlian dan keterampilan, pengetahuan, dan pengembangan jiwa kewirausahaan pelaku-pelaku agroindustri.

Temuan ini sejalan dengan hasil penelitian Anifriza (2016) menyatakan bahwa strategi pengembangan kelapa dapat dilakukan dengan mendirikan pabrik pengolahan kelapa terpadu, meningkatkan mutu produk agar mampu bersaing di pasaran bebas dan memberikan kemudahan akses modal, teknologi dan infomasi, dukungan kebijakan dan pembinaan untuk industri agro. Kelembagaan yang cocok dalam pengelolaan kegiatan agroindustri kelapa adalah Koperasi/Usaha Kecil Menengah (UKM) milik masyarakat/petani kelapa, kriteria yang sangat penting dalam pengelolaan kelembagaan tersebut adalah sumberdaya manusia.

Bentuk industri pengolahan karet yang diharapkan akan dikembangkan di Kabupaten Rokan Hulu adalah pengembangan industri karet antara dengan skor 0,900. Pengembangan agroindustri akan meningkatkan produktivitas secara ekonomi dan kelembagaan serta menstimulasi produksi pertanian primer sehinggga menghasilkan insentif dari sisi permintaan dan penawaran (Priyarsono 2011). Komoditi yang dihasilkan seperti crumb rubber dan sheet. Komoditi tersebut sama seperti komoditi yang dihasilkan dari pabrik karet yang ada diwilayah sekitarnya seperti di Kabupaten Kampar (Gambar 9). 


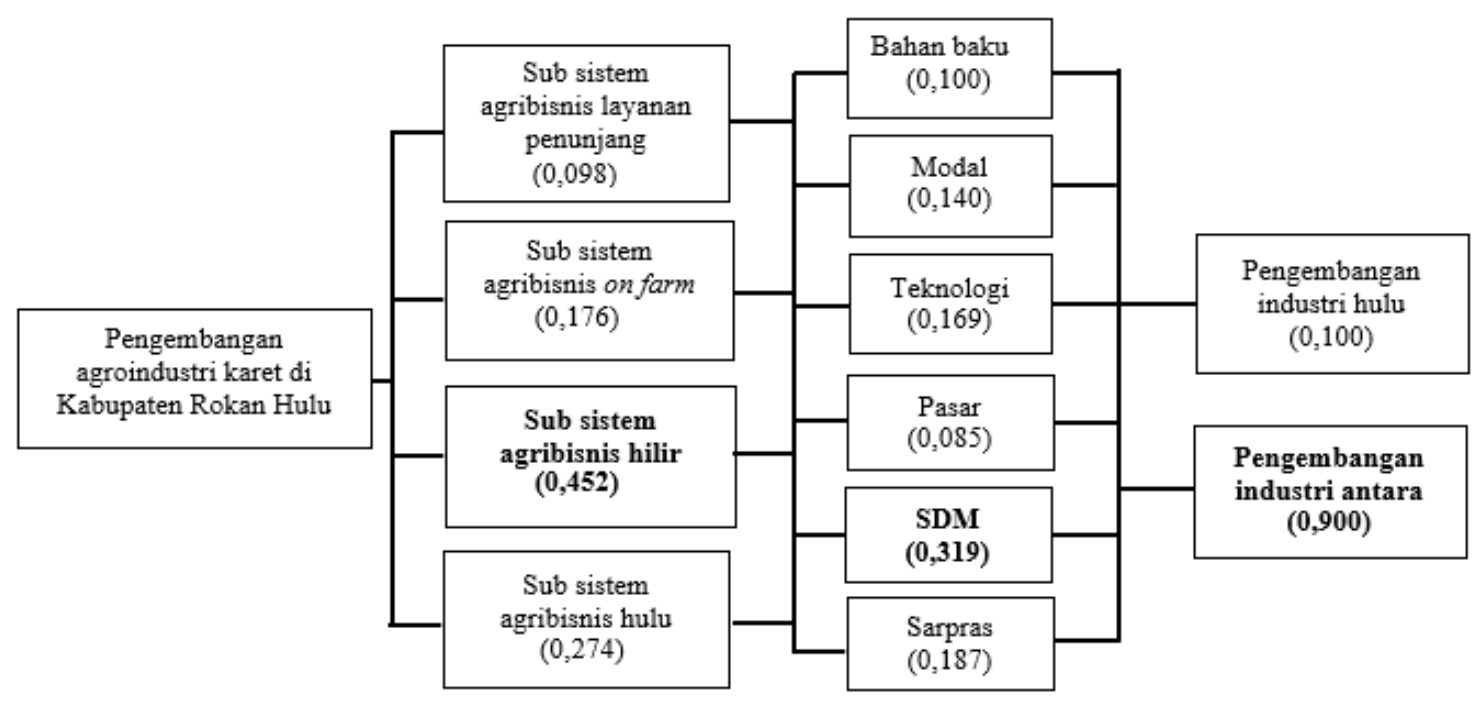

\section{Gambar 13. Alternatif Pengembangan Agroindustri Karet di Kabupaten Rokan Hulu Berdasarkan Persepsi Stakeholders}

\section{KESIMPULAN}

Terdapat 3 jalur pemasaran getah karet di Kabupaten Rokan Hulu yang melibatkan 3 lembaga pemasaran yaitu petani karet, pedagang pengumpul dan pedagang besar. Jalur pemasaran II dan III dianggap jalur yang paling menguntungkan petani karet. Agroindustri karet remah dan karet asap berpotensi meningkatkan pertumbuhan ekonomi di Kabupaten Rokan Hulu. Indikasi tersebut dapat di lihat dari kemampuan sektor industri karet remah dan karet asap dalam mendorong dan menarik pertumbuhan sektor-sektor lainnya yang ditunjukkan dari kuatnya keterkaitan antara sektor industri karet dengan pertumbuhan sektor-sektor ekonomi lainnya (DFL, IFL >1). Sektor industri karet juga banyak memanfaatkan output sektor-sektor lain sebagai input produksinya (DBL, IBL >1), sehingga dapat memicu peningkatan produksi dari sektor-sektor tersebut. Setiap peningkatan permintaan akhir karet remah dan asap sebesar 1 miliar rupiah, berdampak terhadap peningkatan output wilayah sebesar 1.40 miliar rupiah, pendapatan rumah tangga sebesar 1.25 miliar rupiah dan penggandaan NTB sebesar 280 jurupiah. Fokus utama pengembangan agroindustri karet di Kabupaten Rokan Hulu dapat dilakukan melalui pengembangan subsistem agribisnis hilir (industri pengolahan karet). Jenis industri pengolahan karet yang dapat dikembangkan berupa industri karet antara, yaitu industri yang dapat menghasilkan produk seperti crumb rubber dan sheet disertai dengan meningkatkan sumberdaya manusia agar lebih berkualitas, terampil dan handal sehingga kelembagaan agroindustri karet dapat berfungsi maksimal.

\section{DAFTAR PUSTAKA}

[BPS] Badan Pusat Statistik Indonesia. 2014. Indonesia Dalam Angka Tahun 2014. Indonesia (ID): Badan Pusat Statistik Indonesia.

[BPS] Badan Pusat Statistik Kabupaten Kampar. 2015. Kabupaten Kampar Dalam Angka Tahun 2015. Kampar (ID): Badan Pusat Statistik Kabupaten Kampar.

[BPS] Badan Pusat Statistik Kabupaten Rokan Hulu. 2015. Kabupaten Rokan Hulu Dalam Angka Tahun 2015. Rokan Hulu (ID): Badan Pusat Statistik Kabupaten Rokan Hulu. 
Agustian A, Mayrowani H. 2008. Pola Distribusi Komoditas Kentang di Kabupaten Bandung, Jawa Barat. J Ekonomi Pembangunan. 9(1):96-106.

Ahmadi N, Fitriyana G, Sudoni T. 2016. Analisis Pemasaran Bahan Olah Karet (Bokar) dan Pendapatan Petani Karet (Studi Kasus di Desa Surya Adi Kecamatan Mesuji Kabupaten Ogan Komering Ilir). J TriAgro. $1(2): 30-32$.

Anifriza. 2016. Strategi pengembangan agribisnid dan agroindustri kelapa dalam pengembangan wilayah di Kabupaten Padang Pariaman. [Tesis] : Sekolah Pascasarjana Institut Pertanian Bogor.

Antara IM. 2001. Agribisnis Paradigma Baru Ekonomi. J Soca. 1(3):1492-226.

Daniel M. 2002. Pengantar Ekonomi Pertanian. Jakarta (ID): Bumi Aksara.

Daryanto A, Hafizrianda Y. 2010. Analisis Input-Output \& Social Accounting Matrix untuk Pembangunan Ekonomi Daerah. Bogor (ID): IPB Press.

Djakapermana RD. 2010. Pengembangan Wilayah Melalui Pendekatan Kesisteman. Bogor (ID): IPB Press.

Hidayat W, Rustiadi E, Kartodihardjo H. 2014. Dampak Sektor Pertambangan Terhadap Perekonomian Wilayah di Kabupaten Luwu Timur. J Economia. 10(1):77-78.

Kementerian Perindustrian RI. 2009. Peraturan Menteri Perindustrian Nomor 112 Tahun 2009 Tentang Peta Panduan (Road Map) Pengembangan Klaster Industri Karet dan Barang Karet. Jakarta (ID): Kementerian Perindustrian RI.

Krisnamurthi B, Pambudy R, Dabukke F. 2010. Refleksi Agribisnis: 65 Tahun Profesor Bungaran Saragih. Bogor (ID): IPB Press.

Napitupulu D. 2011. Kajian Tataniaga Karet Alam: Upaya Peningkatan Kesejahteraan Petani. J Penelitian Karet. 29(1):84-87.

Priyarsono DS. 2011. Dari Pertanian ke Industri, Analisis Pembangunan dalam Perspektif Ekonomi Regional. Bogor (ID): IPB Press.

Rustiadi E, Saefulhaim S, Panuju DR. 2011. Perencanaan dan Pengembangan Wilayah. Jakarta (ID): Crestpent Press dan Yayasan Pustaka Obor Indonesia.

Saaty TL. 1996. Multicriteria Decision Making: The Analytic Hierarchy Process. RWS Publication, PittsburgUSA. 286 pp.

Saaty TL. 2008. Making Decisions In Hierarchic and Network Systems. Int J applied decision sciences. 1(1): 2479.

Sari FP. 2009. Percepatan Pengembangan Agroindustri di Era Otonomi Daerah Suatu Pendekatan Kajian Konsep. J AgronobiS. 1(2):56-62.

Saragih B. 2010. Suara dari Bogor Membangun Opini Sistem Agribisnis. Bogor (ID): IPB Press.

Sudiyono A. 2001. Pemasaran Pertanian. Malang (ID): UMM Press.

Sugiyono. 2008. Memahami Penelitian Kualitatif. Bandung (ID): Alfabeta.

Syafa'at N, Mardianto S. 2011. Identifikasi Sumber Pertumbuhan Output Nasional: Pendekatan Analisis InputOutput. J Agro Ekonomi. 20(1):20-22.

Tarigan R. 2010. Perencanaan Pembangunan Wilayah. Jakarta (ID): Bumi Aksara.

Tety E, Maharani E, Ningsih F. 2014. Analisis Pemasaran dan Transmisi Harga pada Petani Bahan Olahan Karet (Bokar) di Desa Sei Tonang Kecamatan Kampar Utara Kabupaten Kampar. J Pendidikan Ekonomi dan Bisnis. 6(3):162-165.

Wahyudy H A Azharuddin dan Asrol. 2015. Analisis Strategi Pengembangan Agribisnis Karet Rakyat di Kabupaten Kuantan Singingi, Provinsi Riau. J Dinamika Pertanian. 30(3):254-256. 